\title{
Introduction
}

\section{Ring-Tailed Lemurs: A Species Re-Imagined}

\author{
Michelle L. Sauther ${ }^{a}$ Lisa Gould ${ }^{c}$ Frank P. Cuozzo ${ }^{b}$ \\ M. Teague O'Mara ${ }^{d-f}$
}

${ }^{a}$ Department of Anthropology, University of Colorado, Boulder, Colo., and ${ }^{\mathrm{b}}$ Department of Anthropology, University of North Dakota, Grand Forks, N.Dak., USA; ' $D$ Department of Anthropology, University of Victoria, Victoria, B.C., Canada; ${ }^{\mathrm{d}}$ Zukunftskolleg and

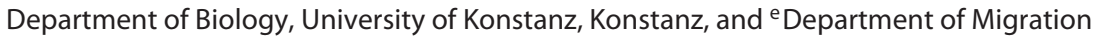
and Immuno-Ecology, Max Planck Institute for Ornithology, Radolfzell, Germany;

${ }^{f}$ Smithsonian Tropical Research Institute, Panamá, Panama

\section{Key Words}

Lemur catta · Ecology · Behaviour · Health · Long-term studies · Conservation

\begin{abstract}
For over 50 years, ring-tailed lemurs have been studied continuously in the wild. As one of the most long-studied primate species, the length and breadth of their study is comparable to research on Japanese macaques, baboons and chimpanzees. They are also one of the most broadly observed of all primates, with comprehensive research conducted on their behaviour, biology, ecology, genetics, palaeobiology and life history. However, over the last decade, a new generation of lemur scholars, working in conjunction with researchers who have spent decades studying this species, have greatly enhanced our knowledge of ring-tailed lemurs. In addition, research on this species has expanded beyond traditional gallery forest habitats to now include high altitude, spiny thicket, rocky outcrop and anthropogenically disturbed coastal forest populations. The focus of this special volume is to 're-imagine' the 'flagship species of Madagascar', bringing together three generations of lemur scholars.

(c) 2015 S. Karger AG, Basel
\end{abstract}

Today, ring-tailed lemurs are essentially one of most recognized lemur species thanks to decades of research and publications, as well as media and films (fig. 1). However, Lydekker even noted this back in 1893, stating it was both the best known and most easily recognized of the true lemurs. The first authoritative western description of ring-tailed lemurs was by Etienne de Flacourt [1658], who states that 'in Ampatra and Maafalles, there are also many white monkeys which are called vary, which have black and white striped tails, travelling in groups of 30, 40 and 50' (p. 153). How-

\section{KARGER 125\% @ 2015 S. Karger AG, Basel \\ E-Mail karger@karger.com www.karger.com/fpr}

Michelle L. Sauther

Department of Anthropology

University of Colorado, 1350 Pleasant St.

Boulder, CO 80309-0233 (USA)

E-Mail sauther@colorado.edu 
Fig. 1. Juvenile ring-tailed lemur, L. catta, in gallery forest at Bezà Mahafaly Special Reserve, Madagascar. Photo by M.L. Sauther.

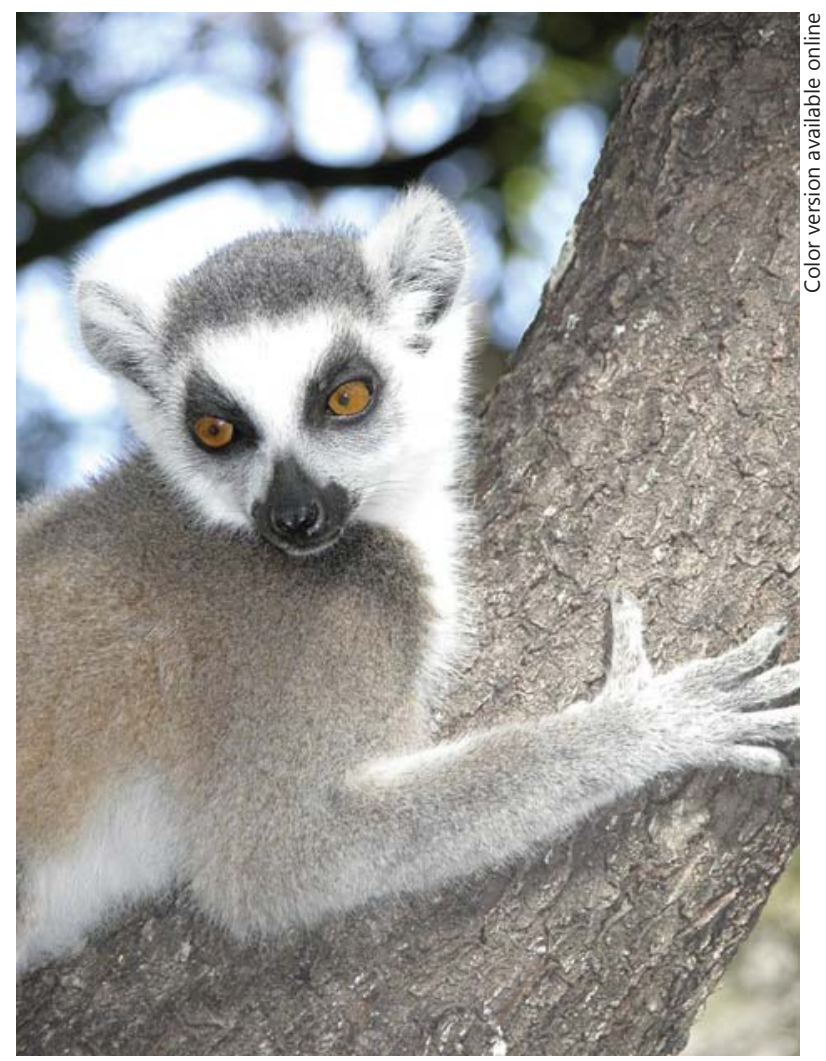

ever, the earliest actual account of wild ring-tailed lemurs may be in Samuel Purchas' Hakluytus Posthumus or Purchas His Pilgrimes [1625] who recounts from the journals of Captain Keeling that near the mouth of the Onilahy River in the Baie de St.-Augustin 'here we found the beautifull beast' (Purchas vol. I, p. 192, cited in Tattersall [1982]) and from William Finch, who accompanied the expedition, who states that 'in the woods neere abouth the River, is a great store of beasts, as big as Munkies, ashcoloured, with a small head, long taile like a Fox, garled with white and blacke, the furre very fine (Purchas vol. I, p. 417, cited in Tattersall [1982]). Other early historical accounts of ring-tailed lemurs include Sibree [1880] who talks of their 'thick bushy tail banded with black and white ... usually coiled, like a comforter, round its neck and who defend themselves with great spirit if attacked' (p. 41) and Rand [1935] who speaks of the importance of their access to water, noting that one captive ring-tailed lemur 'even drank hot chocolate, and whisky and water' (p. 96). More recently, Jolly [1967], in her inimitable way, likened them to a 'Paris-styled raccoon' (p. 3).

The ring-tailed lemur scientific designation was initially quite lively and included names like Catta mococo, Maki mococo, Prosimia catta and even Odorlemur catta, [Wilson and Hanlon, 2010], the latter no doubt reflecting their dramatic 'stink fights'. Of course, their official designation is Linnaeus' Lemur catta [Thomas, 1911]. Given the vagaries of taxonomy, the genus Lemur was originally given to the red slender 


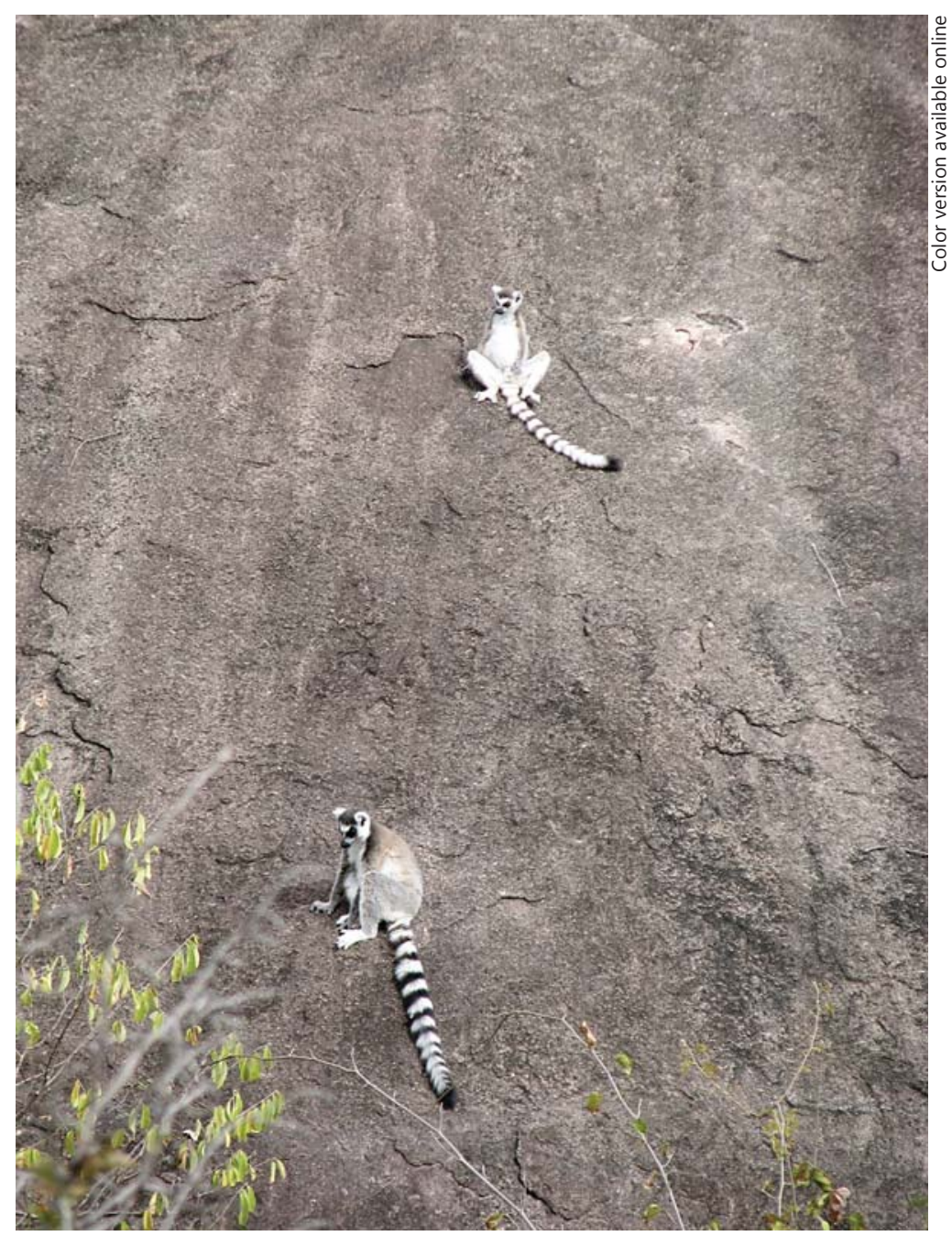

Fig. 2. Ring-tailed lemurs on the rocky-outcrop forest fragments of the south-central highlands of Madagascar. Photo by L. Gould.

loris and also included the Philippine colugo (which is not even a primate). Thomas [1911] carried out a bit of taxonomic archaeology and stated that L. catta is the single type specimen of the genus Lemur, moving the loris into its own genus Loris and the colugo into Cynocephalus. Although controversial, in 1988 the genus Lemur was relegated to catta alone, with the others placed into a new genus Eulemur [Simons and Rumpler, 1988; Tattersall and Schwartz, 1991]. Despite their wide distribution across southern Madagascar, they are, genetically, a single species, despite some geographic variation in coat colour [Goodman and Langrand, 1996]. It is interesting to note that, despite the fact that until recently ring-tailed lemurs were studied primarily in riverine forest, both Sibree [1880] and Lydekker [1893] stated that their habitats in south- 
ern Madagascar are solely among the rocks, both arguing that the characteristics of their hands and feet gave them firm footing on slippery rocks (fig. 2).

While Flacourt was the first to describe them in an academic treatise, the first true study of ring-tailed lemur natural history was Alison Jolly's work at the forest reserves of Berenty Estate in southern Madagascar from 1963 to 1964 [Jolly, 1966; Jolly et al., 2006]. By 1986 another research site, the gallery and spiny forests of the Bezà Mahafaly Special Reserve, was established [Sussman and Ratsirarson, 2006], and together Berenty and Bezà Mahafaly remain the only sites where long-term research on wild ring-tailed lemurs has been carried out. In 1966 the Duke Lemur Center (previously the Duke University Primate Center) was established in Durham, N.C., USA, and continues today as an important research centre for the study of semi-free-ranging ring-tailed lemurs as well as 20 other species of strepsirrhine primates [Moore, 2014]. Since Jolly's seminal work, ring-tailed lemurs have been consistently studied in the wild in Madagascar [Jolly et al., 2006] for over 50 years, with only a slight reduction of research during the late 1970s due to political reasons [Jolly et al., 2006].

In 2006 an important book on ring-tailed lemurs entitled Ringtailed Lemur Biology was published [Jolly et al., 2006], bringing together in one volume what was then known about this species in Madagascar. So one may ask, why another volume just on this species? The idea for this special volume was developed during the 2011 American Association of Physical Anthropologists meeting in Minneapolis. We (Lisa Gould, Frank Cuozzo and Michelle Sauther) were at a restaurant called 'Hell's Kitchen', and during our conversations it became obvious that in the very short 5 years since the publication of that seminal work, there had been an explosion of studies on this species. Most importantly, there were now a whole new generation of ring-tailed lemur scholars who were asking original questions and following this enigmatic species in very new places beyond the traditional gallery forests where the majority of ring-tailed lemur studies had been carried out. On April 10, 2014, 19 researchers (and their many co-authors) convened a special poster symposium on ring-tailed lemurs at the 83rd Annual Meeting of the American Association of Physical Anthropologists in Calgary, Canada. Of the 19 presentations, 11 are included as part of this special volume, with 3 additional invited papers included. Papers presented in this volume bring together three generations of ring-tailed lemur scholars and focus on a variety of dynamic and broad questions important not just to ring-tailed lemur study, but also highly relevant to overall primate biology and ecology.

\section{Summary of Papers}

The papers in this special volume can be arranged along broad themes. As noted before, long-term studies of ring-tailed lemurs have focused on gallery forest populations like those at Berenty and Bezà Mahafaly. However, ring-tailed lemurs have an impressive geographic distribution, being denizens of spiny forests in Berenty (fig. 3), Bezà Mahafaly, Cap Sainte-Marie and Tsimanampesotse, where some groups sleep in caves [LaFleur, 2012; Sauther et al., 2013] (fig. 4), the mountain massifs of Andringitra, the humid forests of Andohahela, as well as other mixed forests in the highland regions of the upper Mangoky River [Goodman, 2006], the rocky-outcrop forest fragments of the south-central highlands [Gould and Gabriel, 2014], and the mangrove forests of south-western Madagascar [Sauther et al., 2013]. Because of recent studies 


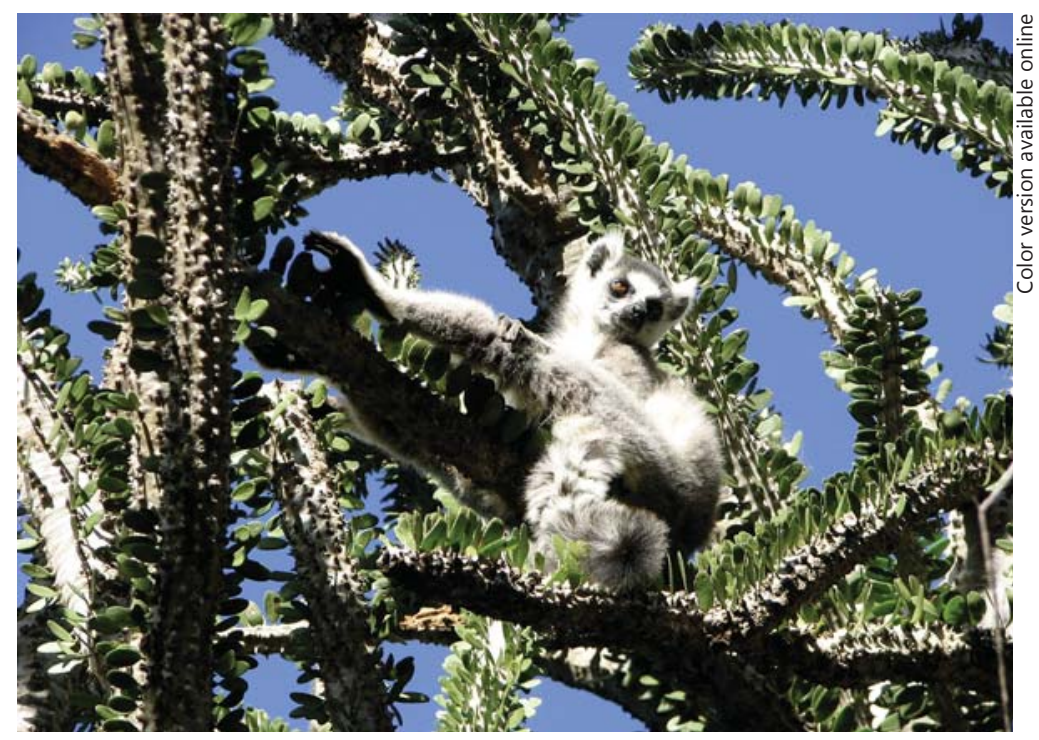

Fig. 3. Ring-tailed lemur in the spiny forest of Berenty, Madagascar. Photo by L. Gould.

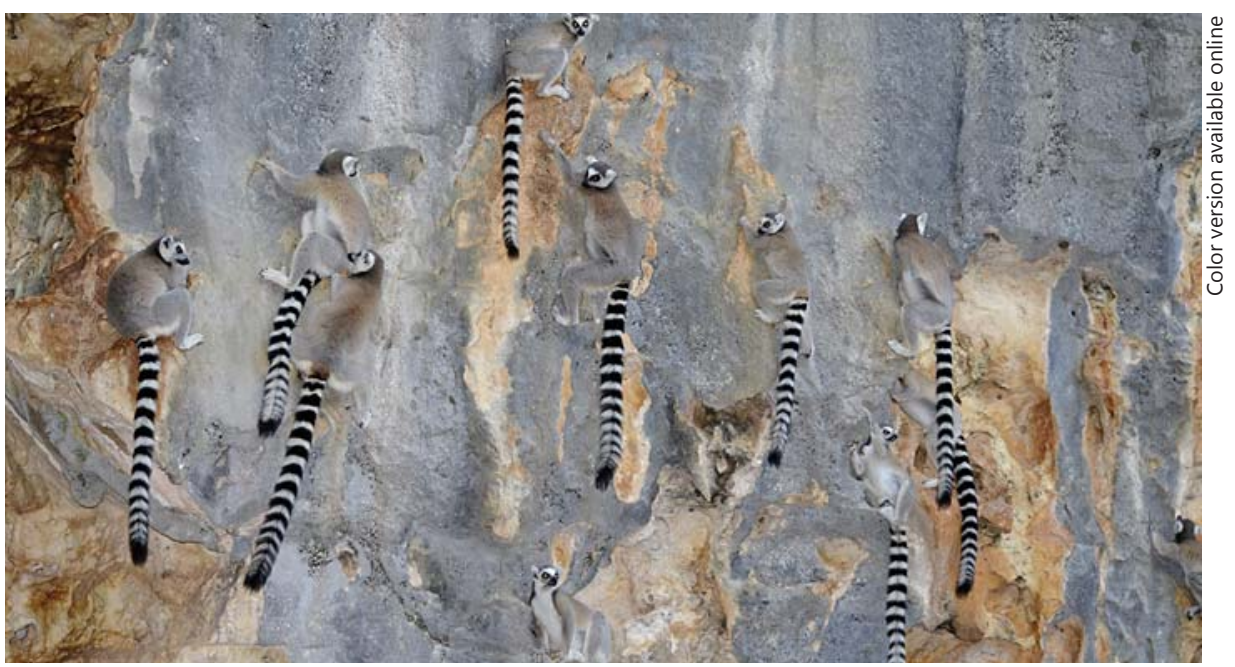

Fig. 4. Ring-tailed lemurs at Tsimanampesotse queuing up to enter sleeping caves. Photo by M. LaFleur.

in spiny and non-gallery forests, it is now possible to make comparisons across habitats which, given the high rates of continuing forest loss in Madagascar, is very important for understanding how different habitat characteristics affect ring-tailed lemur ecology. For example, spiny forest ring-tailed lemurs appear to have feeding strategies that maintain protein resources during lactation irrespective of the type of 
spiny forest habitat. Gould et al. [2015] find that despite differences in plant species across 3 different spiny forest habitats, reproductive female ring-tailed lemurs maintain high protein-to-fibre ratios for preferred plant foods. Certain ring-tailed lemur habitats do appear to have protein advantages, however, as seen by LaFleur and Sauther [2015] who note that, compared to spiny forests, ring-tailed lemurs living in gallery forests dominated by Tamarindus indica (an important food in some gallery forest habitats) ingest higher crude protein, which could be at the potential expense of higher fibre content in their diets. Comparisons across habitats, such as that of Yamashita et al. [2015] comparing gallery forest and dry and spiny forest at Bezà Mahafaly find that ring-tailed lemur diets in different habitats comprise a mixture of 'core' plants which are eaten regardless of their abundance and availability. Their study also adds to the growing consensus that high lemur population densities may not be as tightly tied to $T$. indica densities as previously thought. Overall these papers add to our understanding of the ecological flexibility of this species.

Assessing the health status of ring-tailed lemurs is also important in terms of conservation as well as understanding seasonal effects. Millette et al. [2015] demonstrate the effectiveness of a non-invasive way to assess ring-tailed lemur health status by using visual measures of coat and body condition. They find that coat and body condition vary relative to seasonal resource availability (dry vs. wet season) and that lactating females exhibit lower body condition scores when compared to males and non-lactating individuals, suggesting higher energetic costs associated especially with lactation. Singleton et al. [2015] compare health values for ring-tailed lemurs living within the Bezà Mahafaly riverine gallery forest with those living in a nearby degraded mixed dry deciduous and Alluaudia-dominated spiny forest during the dry season, when there is reduced food and water resources. Biomedical values indicate that while lemurs living in more anthropogenically degraded habitat maintain similar body weights, they do show evidence of dehydration compared to the gallery forest lemurs. This could relate to the extensive livestock grazing causing a reduction in the understorey plants and hence fewer food resources that could provide dietary water being available to the lemurs.

Genetic data have become an important research tool in understanding primate dispersal patterns, effects of habitat fragmentation and even microbiome variation. Parga et al. [2015] assess gene flow and dispersal patterns in 2 populations of wild ring-tailed lemurs at Bezà Mahafaly and Tsimanampesotse and find that the 2 populations may have had historical gene flow. In addition, while the Tsimanampesotse lemurs show male-biased dispersal, the Bezà Mahafaly population supports occasional female dispersal by small groups of related kin, which may be driven by intense resource competition at this site. Clarke et al. [2015] measured genetic diversity in forest fragments in south-central Madagascar and find that while these relatively smaller populations have not yet lost significant genetic variation, we may be looking at populations experiencing a time-lagged response before harmful losses of genetic variation. Finally, gut microbiome data are essential to metabolism, but few studies have looked at this in wild mammals. In the first study of wild ring-tailed lemur and sifaka microbiomes, Fogel [2015] extracted and sequenced microbial DNA and finds that different populations of lemurs have quite distinct microbiomes, with seasonality leading to reversible changes in gastrointestinal flora.

Studies of wild ring-tailed lemur behavioural ecology have also expanded greatly. For example, given the large group sizes that are common for ring-tailed lemurs, several papers in this volume indicate the importance of sociality in understanding 
various aspects of $L$. catta behaviour. O'Mara [2015] finds limited support for the ecological risk aversion hypothesis. This posits that an extended primate juvenile period is related to minimizing risks of predation, which forces juveniles to feed in the centre of a group or near others which thus requires decreased growth rates and an extended juvenile period to mitigate feeding competition. Instead, he suggests sociality and social complexity may play more important roles. Similarly, Kittler et al. [2015] contribute an accessible, up-to-date review paper of ring-tailed lemur cognition. Recent work illustrates that L. catta is similar in its physical cognitive abilities to other lemurs and some haplorhine primates, and its abilities in some areas of social cognition, notably those related to group living, exceed those of other, less socially complex lemurs. The importance of including strepsirrhine primates in the analyses of broad questions is also highlighted in the paper by Meredith [2015], who finds that adding data from wild ring-tailed lemurs to haplorhine data in a Bayesian Markov chain Monte Carlo model increases the already significant support for juvenile interest in infants being selected to facilitate learning to care for infants as an adult. Ecological factors such as predation do, however, play important roles for other aspects of ring-tailed lemur behavioural ecology. For example, Bolt et al. [2015] find that male ring-tailed lemurs play an important role in antipredator behaviours, with males consistently participating in group level antipredator vocalizations in high-risk locations, and that they are key participants in group-wide behaviours to confuse or drive away potential predators. The paper by Ichino et al. [2015] exemplifies the importance of long-term studies. Based on a 24-year longitudinal data set, they report that female ring-tailed lemurs that survive their first year exhibit a mean lifespan of only 6.6 years, with especially high mortality rates associated with 12 - to 15 -year-olds. Nevertheless, these older females commonly give birth in the last years of their life, indicating no evidence for a postreproductive lifespan for $L$. catta. Finally, the paper by Cuozzo and Sauther [2015] also demonstrates the efficacy of using long-term data on extant $L$. catta to understand the biology of past lemur communities. They assess patterns of tooth wear in a Holocene ( $~ 500$ to $\sim 600 \mathrm{BP})$ sympatric subfossil L. catta and Eulemur rufifrons assemblage that lived within the transitional humid-dry forest and succulent woodland habitat of Ankilitelo in comparison to patterns of tooth wear in the Bezà Mahafaly population of ring-tailed lemurs living in tamarind-dominated gallery forest. This extant population demonstrates high levels of tooth wear and loss that is linked to the continuous use of $T$. indica, a fallback food for which this species is not dentally adapted [Cuozzo and Sauther, 2006]. E. rufifrons wear patterns suggest that it was consuming more mechanically challenging foods than L. catta, and this indicates some level of niche partitioning at this site. However, neither species shows the pattern or extent of wear linked to high T. indica use, intimating that Ankilitelo may have been one of the last intact refugia in the south-west spiny thicket.

What, then, may the next 50 years hold for studies of this highly flexible and adaptive species? Last year saw the passing of a great pioneer in ring-tailed lemur studies, Alison Jolly [Nekaris et al., 2015]. Nevertheless, her legacy lives on in the work of her many students and associates. Other challenges remain. As noted by many of the researchers contributing to this volume, the flagship species of Madagascar is now facing major threats that include hunting for the bush meat trade, capturing infants for tourists [Sauther et al., 2013], extreme fragmentation of formerly large forested areas, prohibiting male dispersal and gene flow [Gould and Gabriel, 2014] and continuing habitat degradation and destruction by oil and mineral concessions [Gould and Gabriel, 
2013; Malone et al., 2013; Schwitzer et al., 2013]. Indeed, L. catta's conservation status has jumped from vulnerable to endangered in only 6 years [Schwitzer et al., 2013], and this species needs to be the immediate focus of new conservation initiatives. The ability of this species to maintain itself in small fragments is undoubtedly limited [Cameron and Gould, 2013]. For example, in south-eastern Madagascar 60\% of littoral forests are now gone, with ring-tailed lemurs in the small fragmented littoral forest of Petriky now essentially extinct [Malone et al., 2013; Gould, pers. commun.]. It is therefore imperative that studies of ring-tailed lemurs be conducted outside gallery forests, especially along continuous riverine corridors within these fragmented landscapes, to provide specific census and genetic information which will facilitate a better understanding and maintenance of potential dispersal routes. In addition, continuing studies of ring-tailed lemurs in small fragments are documenting that this species can survive on introduced plant species [Gould and Gabriel, 2014], and such data are critical to developing immediate conservation plans, especially in collaboration with conservation initiatives by local villagers [Gould and Gabriel, 2013, 2014]. As noted by Kay [2004], 'it remains to be seen how many more of the endemic species that Flacourt recorded and published will become mere illustrations in books, like the mysterious Elephant Bird and the curious Giant Lemur' (p. 257).

\section{References}

Bolt LM, Sauther ML, Cuozzo FP, Youssouf Jacky IA (2015). Antipredator vocalization usage in the male ring-tailed lemur (Lemur catta). Folia Primatologica 86: 124-133.

Cameron A, Gould L (2013). Fragment adaptive behavioral strategies and inter-site variation in the ringtailed lemur (Lemur catta) at Anja Special Reserve and the Tsaranoro Valley, south-central Madagascar. In Primates in Fragments (Marsh L, Chapman C, eds.), 2nd ed., pp 227-243. New York, Springer.

Clarke TA, Gray O, Gould L, Burrell AS (2015). Genetic diversity of the ring-tailed lemur (Lemur catta) in south-central Madagascar. Folia Primatologica 86: 76-84.

Cuozzo FP, Sauther ML (2006). Severe wear and tooth loss in wild ring-tailed lemurs (Lemur catta): a function of feeding ecology, dental structure, and individual life history. Journal of Human Evolution 51: 490-505.

Cuozzo FP, Sauther ML (2015). Patterns of dental macrowear in subfossil Lemur catta from Ankilitelo Cave, Madagascar: indications of ecology and habitat use over time. Folia Primatologica 86: 140149.

De Flacourt E (1658). Histoire de la Grande Isle de Madagascar composée par le Sieur de Flacourt, 2 vols. Paris, G. de Lvyne.

Fogel AT (2015). The gut microbiome of wild lemurs: a comparison of sympatric Lemur catta and Propithecus verreauxi. Folia Primatologica 86: 85-95.

Goodman SM, Rakotoarisoa SV, Wilmé L (2006). The distribution and biogeography of the ring-tailed lemur (Lemur catta) in Madagascar. In Ring-tailed Lemur Biology: Lemur catta in Madagascar (Jolly A, Sussman RW, Koyama N, Rasamimanana H, eds), pp 3-15. New York, Springer.

Goodman SM, Langrand O (1996). A high mountain population of the ring-tailed lemur Lemur catta on the Andringitra Massif, Madagascar. Oryx 30: 259-268.

Gould L, Gabriel DN (2013). Anja community reserve and the Association Anja Miray (AMI). In Lemurs of Madagascar: A Strategy for Their Conservation (Schwitzer C, Mittermeier RA, Davies M, Johnson SE, Ratsimbazafy J, Razafindramanana J, Louis EE Jr, Rajaobelina S, eds.), pp 157-158. Bristol, IUCN SSC Primate Specialist Group, Bristol Conservation and Science Foundation and Conservation International.

Gould L, Gabriel DN (2014). Wet and dry season diets of the Endangered Lemur catta (ring-tailed lemur) in two mountainous rocky-outcrop forest fragments in south-central Madagascar. African Journal of Ecology 2014, Epub ahead of print.

Gould L, Kelley EA, LaFleur M (2015). Reproductive female feeding strategies in spiny forest-dwelling Lemur catta in southern and southwestern Madagascar: how do females meet the challenges of reproduction in this harsh habitat? Folia Primatologica 86: 16-24. 
Ichino S, Soma T, Miyamoto N, Chatani K, Sato H, Koyama N, Takahata Y (2015). Lifespan and reproductive senescence in a free-ranging ring-tailed lemur (Lemur catta) population at Berenty, Madagascar. Folia Primatologica 86: 134-139.

Jolly A (1966). Lemur Behavior. Chicago, University of Chicago Press.

Jolly A (1967). Breeding synchrony in wild Lemur catta. In Social Communication among Primates (Altman SA, ed.), pp 3-14. Chicago, University of Chicago Press.

Jolly A, Koyama N, Rasamimanana H, Crowley H, Williams G (2006). Berenty Reserve: a research site in southern Madagascar. In Ringtailed Lemur Biology: Lemur catta in Madagascar (Jolly A, Sussman RW, Koyama N, Rasamimanana H, eds.), pp 32-42. New York, Springer.

Kay J (2004). Etienne de Flacourt, L'Histoire de le Grand Ile de Madagascar (1658). Curtis Botanical Magazine 21: 251-257.

Kittler K, Schnoell AV, Fichtel C (2015). Cognition in ring-tailed lemurs. Folia Primatologica 86: 106-116.

LaFleur M (2012). Ecology of Ring-Tailed Lemurs (Lemur catta) at the Tsimanampetsotsa National Park, Madagascar: Implications for Female Dominance and the Evolution of Lemur Traits. PhD dissertation, University of Colorado, Boulder.

LaFleur M, Sauther ML (2015). Seasonal feeding ecology of ring-tailed lemurs: a comparison of spiny and gallery forest habitats. Folia Primatologica 86: 25-34.

Lydekker R (1893). The Royal Natural History, vol 1. London, Frederick Warne \& Co.

Malone M, Ramanamanjato JB, Randriatfika F, Donati G (2013). Habitat structure and grey mouse lemur (Microcebus murinus) abundance in the transitional littoral forest of Petriky, south-east Madagascar. Lemur News 17: 22-26.

Meredith SL (2015). Anchoring the clade: primate-wide comparative analysis supports the relationship between juvenile interest in infants and adult patterns of infant care. Folia Primatologica 86: 117-123.

Millette JB, Sauther ML, Cuozzo FP (2015). Examining visual measures of coat and body condition in wild ring-tailed lemurs at the Bezà Mahafaly Special Reserve, Madagascar. Folia Primatologica 86: 44-55.

Moore A (April 16, 2014). History of the Duke Lemur Center. The chronicle. http://www.dukechronicle. com/articles/2014/04/16/history-duke-lemur-center.

Nekaris KAI, Soma T, Gould L (2015). Dr Alison Jolly. Folia Primatologica 86: 14-15.

O’Mara MT (2015). Ecological risk aversion and juvenile ring-tailed lemur feeding and foraging. Folia Primatologica 86: 96-105.

Parga JA, Sauther ML, Cuozzo FP, Youssouf Jacky IA, Gould L, Sussman RW, Lawler RR, Pastorini J (2015). Genetic evidence for male and female dispersal in wild Lemur catta. Folia Primatologica 86: 66-75.

Purchas S (1625). Hakluytus Posthumus or Purchas His Pilgrimes, 5 vols. London, Henry Fetherston.

Rand AL (1935). On the habits of some Madagascar mammals. Journal of Mammalogy 16: 89-104.

Sauther ML, Cuozzo FP, Youssouf JIA, Fish KD, LaFleur M, Ravelohasindrazana LAL, Ravoavy JF (2013). Limestone cliff-face and cave use by wild ring-tailed lemurs (Lemur catta) in southwestern Madagascar. Madagascar Conservation and Development 8: 73-80.

Schwitzer C, Mittermeier RA, Davies M, Johnson SE, Ratsimbazafy J, Razafindramanana J, Louis EE Jr, Rajaobelina S (2013). Lemurs of Madagascar: A Strategy for Their Conservation. Bristol, IUCN SSC Primate Specialist Group, Bristol Conservation and Science Foundation and Conservation International.

Sibree J (1880). The Great African Island: Chapters on Madagascar. Ludgate Hill, Trübner \& Co.

Simons EL, Rumpler Y (1988). Eulemur: new generic name for species of Lemur other than Lemur catta. Comptes Rendus de l'Académie des Sciences - Series III 307: 547-551.

Singleton CL, Norris AM, Sauther ML, Cuozzo FP, Youssouf Jacky IA (2015). Ring-tailed lemur (Lemur catta) health parameters across two habitats with varied levels of human disturbance at the Bezà Mahafaly Special Reserve, Madagascar. Folia Primatologica 86: 56-65.

Sussman RW, Ratsirarson J (2006). Beza Mahafaly Special Reserve: A research site in southwestern Madagascar. In Ringtailed Lemur Biology: Lemur catta in Madagascar (Jolly A, Sussman RW, Koyama N, Rasamimanana H, eds.), pp 43-51. New York, Springer.

Tattersall I (1982). The Primates of Madagascar. New York, Columbia University Press.

Tattersall I, Schwartz JH (1991). Phylogeny and nomenclature in the 'Lemur-group' of Malagasy strepsirrhine primates. Anthropological Papers of the American Museum of Natural History 69: 1-18.

Thomas O (1911). The mammals of the tenth edition of Linnaeus; an attempt to fix the types of the genera and the exact bases and localities of the species. Proceedings of the Zoological Society of London 1911: 120-158.

Wilson DE, Hanlon E (2010). Lemur catta (Primates: Lemuridae). Mammalian Species 42: 58-74.

Yamashita N, Sauther ML, Cuozzo FP, Youssouf Jacky IA (2015). Beyond the gallery forest: contrasting habitat and diet in Lemur catta troops at Bezà Mahafaly Special Reserve. Folia Primatologica 86: 35-43. 